Article

\title{
Techno-Economic Models for Optimised Utilisation of Jatropha curcas Linnaeus under an Out-Grower Farming Scheme in Ghana
}

\author{
Isaac Osei 1,3, Joseph O. Akowuah ${ }^{2,3}$ and Francis Kemausuor 2,3,* \\ 1 Institute of Industrial Research, Council for Scientific and Industrial Research, Accra, Ghana; \\ iosei0531@gmail.com \\ 2 Department of Agricultural Engineering, Kwame Nkrumah University of Science and Technology, \\ Kumasi, Ghana; akowuahjoe@yahoo.co.uk \\ 3 The Energy Center, Kwame Nkrumah University of Science and Technology, Kumasi, Ghana \\ * Correspondence: kemausuor@gmail.com; Tel.: +233-207-457-532
}

Academic Editor: Christa Liedtke

Received: 31 August 2016; Accepted: 5 November 2016; Published: 10 November 2016

\begin{abstract}
Techno-economic models for optimised utilisation of jatropha oil under an out-grower farming scheme were developed based on different considerations for oil and by-product utilisation. Model 1: Out-grower scheme where oil is exported and press cake utilised for compost. Model 2: Out-grower scheme with six scenarios considered for the utilisation of oil and by-products. Linear programming models were developed based on outcomes of the models to optimise the use of the oil through profit maximisation. The findings revealed that Model 1 was financially viable from the processors' perspective but not for the farmer at seed price of $\$ 0.07 / \mathrm{kg}$. All scenarios considered under Model 2 were financially viable from the processors perspective but not for the farmer at seed price of $\$ 0.07 / \mathrm{kg}$; however, at seed price of $\$ 0.085 / \mathrm{kg}$, financial viability was achieved for both parties. Optimising the utilisation of the oil resulted in an annual maximum profit of $\$ 123,300$.
\end{abstract}

Keywords: jatropha; out grower farming scheme; techno-economic models; profit optimization

\section{Introduction}

Diminishing fossil fuel sources coupled with concerns about climate change presents the need to focus on renewable energy sources to address the escalating energy demands of growing economies like Ghana. Ghana in recent times has therefore developed policies in an effort to ensure the development of renewable energy and its integration into the national energy mix. Key among such policies is the Ghana's Renewable Energy Act (Act 832), which was established in 2011 and has since rejuvenated interest in the development and investment in the renewable energy sector. Within the energy sector, biofuel production is considered to play a significant role due to the potential for sustainable development in rural areas. The establishment of Ghana's draft bioenergy policy was there developed to aim at substitution of national petroleum fuels consumption with biofuel by $10 \%$ by 2020 and $20 \%$ by 2030 [1]. Though, these targets may not be achieved because of the short time span [2] efforts at cultivating promising biofuel crops to achieve the set targets in the long term must be considered a national priority. Among various biofuel crops, Jatropha is identified to have the greatest potential to contribute towards meeting the targets [1].

Jatropha is a shrub crop which can reach a height of $5 \mathrm{~m}$, but can grow up to $10 \mathrm{~m}$ under favourable conditions [3]. It is easily established and grows very quickly with a gestation period of only a year. The plant can be cultivated in large-scale plantation or grown as hedges in homestead and around farms. The shrub starts bearing fruit from the first year of planting but economic yield start from 
the third year [4]. Jatropha has a lifespan of 40-50 years and, according to [5], annual seed yield ranges from 0.4 to $12 \mathrm{t} / \mathrm{ha}$. The major energy carriers from jatropha are the raw oil and its esters. Recent studies have reported the utilisation of the oil for biodiesel production, direct use in modified diesel engines and for soap production [6-8]. The by-products such as the press cake and fruit hulls can also be diversified into a range of bioenergy sources through gasification, briquetting, anaerobic digestion, pyrolysis and combustion.

It is often argued that, for jatropha to fulfil the promise of contributing to sustainable rural development, its cultivation must be small in scale, inclusive and community-based [9,10]. Jatropha cultivation in Africa has in some areas been deployed as large-scale stand-alone plantation as well as out-grower model schemes and a mixture of both in some situations. The most prevalent farming model is, however, large-scale plantation [11]. Currently, jatropha production and processing schemes emerging in Africa include; large scale plantation, contracting small holders as out-growers [12] and independent small-scale farmers (some organised in associations or cooperatives) who are locally producing, processing and utilising the oil in their communities [13]. Plantation scheme has been reported to be more effective, however, concerns have been raised on the use of large stretch of land and its consequential effects on food security and the environment. Case studies into the failure of jatropha cultivation businesses using the large scale plantation model has been reported in Sub-Saharan African countries including Ghana [14-16] However, cultivation of jatropha as a hedge plant in poor rural areas without alternative income generation opportunity has been reported to be the most profitable [14,17]. This is corroborated by [18], who also reported that, the only profitable business case for jatropha is where farmers are planting the crop as hedges.

Out-grower scheme based on strong farmer based organisations (FBOs) in countries with weak agricultural infrastructure can be the best model to uplift poor rural communities. This model has been demonstrated for high value cash crop such as cocoa in Ghana. However, these cannot be extrapolated into the same context with jatropha. Unlike cocoa, jatropha is a low value crop which presents the need for a more diversified utilisation of its oil and by-products in other to make it economically attractive for processors and farmers. Out-grower farming scheme is more preferable over large-scale plantations since large size of land is not required and farmers cultivate the seeds on their own lands. However, despite the expected benefits an out-grower scheme offers ahead of plantation scheme, economic studies have indicated otherwise. A study by [19] on economic viability of an out-grower model indicated that, the estimated financial profitability was bad for seed growers even at relatively good seed market price of $\$ 0.14 / \mathrm{kg}$, but it was marginal for the processors. In a later study, [17] asserted that jatropha production and processing projects that link seed production with local processing and utilisation of the oil is likely to achieve financial viability. It was furthermore reported that finding higher value use of the by-products after processing is likely to increase the prospects of financial viability for both processors and farmers.

Recent reported failures of large scale jatropha plantation in Ghana [16] provides the need for critical consideration of the out-grower model which has been reported to contribute to sustainable development in rural areas. However, given the economic uncertainties and risk of failure, rural poor farmers and processors are not expected to likely take up production without technical and economic assessments that points to sound economic benefit for both the processor and farmer. The balance for achieving economic viability for the processors and farmers that ensure sustainable seed production and corresponding processing and utilisation of the oil and its by-products requires researchers' urgent attention. This study therefore seeks to develop techno-economic models for optimised utilisation of jatropha oil and its by-products under an out-grower farming scheme. Specifically, the financial viability of jatropha production and processing for two business models under the out-grower farming scheme using Net Present Value (NPV) and Internal Rate of Return (IRR) was determined. Linear programming model was also developed to optimise the use of the crude jatropha oil for profit maximization. 


\section{Materials and Methods}

The methodology for this study consisted of three main sections, interview with key informants and literature information on costs and technical parameters in jatropha, briquette, biogas, compost, soap and electricity production (see Appendix A). The data were fed into the two business models considered to determine its economic viability. Linear programming models were later developed to optimise the use of jatropha oil based on data from the models. Detailed description of the methods, materials and models are presented in the sections below.

\subsection{Models Description}

Two business models were developed based on different utilisation of jatropha crude oil and its by-products under an out-grower farming scheme. Total out-grower farmers farm sizes totalling 200 ha was considered as base scenario for the technical and cost benefit analysis of the two models. This was premised on the average plantation size that was established in Ghana in the past. Profitability before tax was considered in the Cost-Benefit Analysis (CBA) of the models.

\subsubsection{Description of Model 1}

In this model, small holder farmers or farmer groups (out-growers) are contracted by a central company to produce jatropha seeds by means of intercropping or as hedges. This model uses the buy-back agreement at fixed price method where a processing company signs an agreement with farmers in which the farmer agrees to sell all his/her produce to the processing company. The company agrees to buy all the seed at a fixed price per kilogram. After the fruits are harvested, collected and de-hulled, the seeds are pressed. The extracted oil is exported. In this model, seedlings, extension services and capacity building are provided to farmers. The pressed cake is used to produce compost and sold to farmers at a subsidised price as a fertiliser supplement. The model outlay is shown in Figure 1.

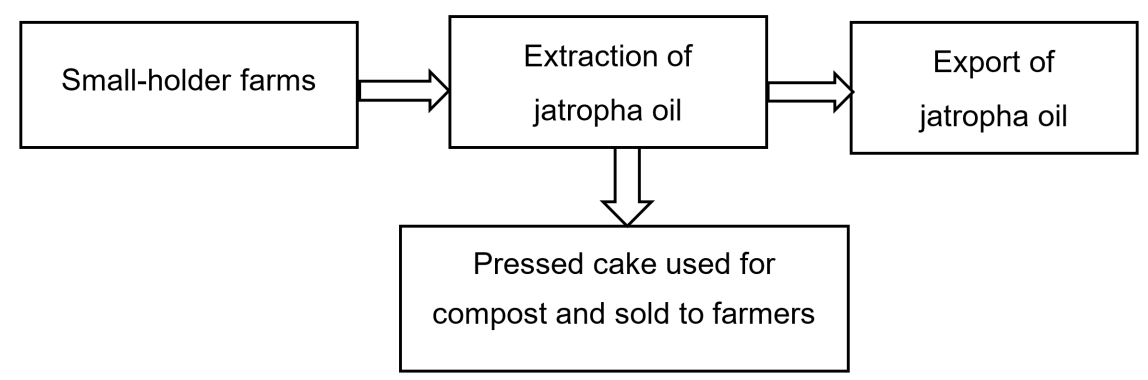

Figure 1. Schematic description of Model 1.

\subsubsection{Description of Model 2}

This model builds on Model 1 with 100\% local utilisation of the oil (Model 1 had an export component) and utilisation of by-products for soap, biogas and briquette production (see Figure 2). Six main scenarios (see Table 1) were considered under this model. 


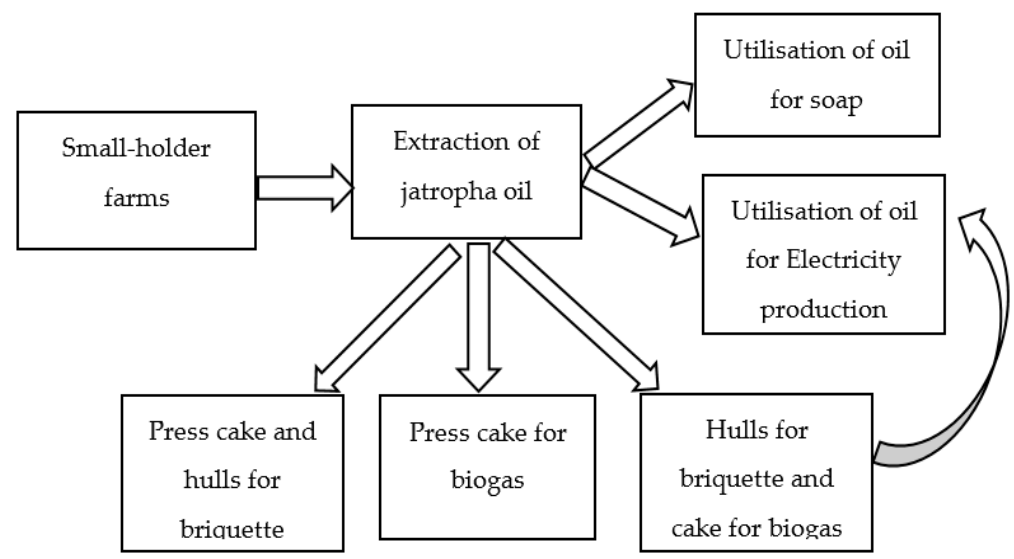

Figure 2. Schematic description of Model 2.

Table 1. Descriptions of scenarios under Model 2.

\begin{tabular}{cl}
\hline Scenario & \multicolumn{1}{c}{ Description } \\
\hline Scenario 1 (S1) & $\begin{array}{l}\text { Utilisation of oil for electricity generation, residual oil for soap and press cake for } \\
\text { biogas production. }\end{array}$ \\
Scenario 2 (S2) & $\begin{array}{l}\text { Utilisation of oil and biogas for electricity generation and residual oil for soap production. } \\
\text { Utilisation of oil for electricity, press cake for biogas, fruit hulls for briquette and residual } \\
\text { oil for soap production. }\end{array}$ \\
Scenario 3 (S3) & $\begin{array}{l}\text { Utilisation of oil for electricity generation, residual oil for soap production, press cake and } \\
\text { fruit hulls for briquette production. }\end{array}$ \\
Scenario 4 (S4) & $\begin{array}{l}\text { Utilisation of filtered and residual oil for soap production, press cake for biogas and fruit } \\
\text { hulls for briquette production. }\end{array}$ \\
Scenario 5 (S5) & Utilisation of filtered and residual oil for soap production, press cake and hulls for \\
\hline
\end{tabular}

\subsection{Financial Appraisal Methodology}

\subsubsection{Financial Return on Investment}

The method used for the determination of the financial return was the Discounted Cash Flow (DCF) approach. The purpose of the financial analysis was to use the projects cash flow forecasts to calculate suitable net return indicators. Emphasis was placed on two financial indicators: Net Present Value (NPV) and Internal Rate of Return (IRR). The NPV was determined using Equation (1):

$$
N P V=\sum_{t=0}^{n} a_{t S_{t}}=\frac{S_{0}}{(1+i)^{0}}+\frac{S_{1}}{(1+i)^{1}}+\ldots+\frac{S_{n}}{(1+i)^{n}}
$$

where $S_{t}$ is the balance of cashflow at time " $t$ "; $a_{t}$ is the financial discount factor; $a_{t}=\frac{1}{(1+i)^{t}}$, where $t$ is the time between 0 and $n$ (the time horizon) and $i$ is the discount rate.

The IRR was calculated using Equation (2):

$$
N P V(S)=\sum \frac{S_{t}}{(1+I R R)^{t}}=0
$$

where symbols have same meaning as in Equation (1).

Cash flows were discounted over a period of 25 years for jatropha plantation, 25 years for the electricity generation, biogas production and oil extraction, 20 years for briquette, compost and soap production at a rate of $18 \%$ which is Ghana's inflation rate as at 26 June 2015 [20]. A rate of 
$5 \%$ of equipment and machinery cost was assumed to be operation and maintenance cost in the financial analysis.

\subsubsection{Estimation of Costs and Revenue}

Method used in the estimation of the various cost components (investment, working capital and operation and maintenance cost) of the projects consisted of interview with key stakeholders and data from literature (see Appendix A). The respondents consisted of various stakeholders in jatropha, biogas, briquettes, compost and soap production businesses. The investment cost included cost of building, machinery and civil works, cost incurred for jatropha plantation, and other expenses. The operating costs comprise all the data on the disbursements foreseen for the purchase of goods and services, which are not of an investment nature since they are consumed within each accounting period. The data were organised into three main categories:

(1) The direct production costs (consumption of materials and services, personnel, maintenance, general production costs).

(2) Administrative and general expenditures.

(3) Sales and distribution expenditures.

The total revenue to be accrued includes revenues from: crude jatropha oil, electricity, soap, biogas, briquettes, and compost. The unit price of all items was determined using the relation shown in Appendix A.

\subsubsection{Criteria for Assessing the Projects Viability}

As indicated earlier the economic indicators used to assess the projects viability was the NPV and IRR. If the NPV of a prospective project is positive, the project is accepted. However, if NPV is negative, the project is considered not financially viable and rejected. In ranking projects, the one with higher NPV is preferred. The higher a project's internal rate of return, the more desirable it is to undertake the project. As such, IRR was used to rank the two business models. A business model that depicted IRR lower than the interest on savings at 25\% [21], was considered not financially viable.

\subsubsection{Sensitivity Analysis}

Sensitivity analysis was carried out by varying one element at a time and determining the effect of that change on IRR and NPV. The key parameters considered included:

(1) Variation in seed yield: $0.55,4$ and 7.5 tonnes/ha.

(2) Variation in jatropha oil prices: 473, 600 and 1000 USD per tonne.

(3) Variation in the purchase price of jatropha seeds: 0.05, 0.07 and 0.16 USD per kg.

(4) Thirty per cent increase and decrease in the selling price of briquette, biogas, soap, compost and electricity.

(5) Changes in the discount rate: discount rates from $0 \%$ to $30 \%$ were considered.

\subsection{Methodology for Optimising Jatropha Oil and By-Products Utilisation}

Every business establishment seeks to maximise profit with the available resources. This section of the study therefore sought to optimise utilisation of jatropha oil through profit maximisation. A linear programming model was therefore developed with set objective functions and constrains. The set objective function, which is a mathematical function that consists of a decision variable denoted with $(Z)$, was used to represent maximised profit or minimised cost. On the other hand, the constrains denoted with (C) which may be represented with an equation or no equation using decision variables was used to express the limitations of the model or decision in order to research the model objectives as reported by [22]. The linear programming models were solved using Excel 2016 optimisation tool. Table 2 presents the objective functions and constraints. 
Table 2. Objective function and constraints for optimising the utilisation of jatropha oil.

\begin{tabular}{cc}
\hline Objective Function & Constraints \\
\hline & $C_{1}: X_{1}+a X_{2}+b X_{3} \leq g$ \\
$Z_{1}=$ Maximize $(P)=F_{1} X_{1}+F_{2} X_{2}+F_{3} X_{3}$ & $C_{3}: X_{1} \leq 0.6 g$ \\
& $C_{4}: X_{3} \leq 0.7 d$ \\
& $C_{5}: X_{1}, X_{2}, X_{3} \geq 0$
\end{tabular}

where $\mathrm{X}_{1}=$ Quantity of oil required for export $(\mathrm{L}) ; \mathrm{X}_{2}=$ Quantity of electricity required $(\mathrm{kWh}) ; \mathrm{X}_{3}=$ Quantity of soap required $(\mathrm{kg}) ; \mathrm{F}_{1}=$ Unit profit of oil export $(\mathrm{USD} / \mathrm{L}) ; \mathrm{F}_{2}=$ Unit profit of Electricity generation $(\mathrm{USD} / \mathrm{kWh})$; $\mathrm{F}_{3}=$ Unit profit of soap production (USD $/ \mathrm{kg}$ ); $\mathrm{P}=$ Maximum profit (USD); $\mathrm{a}=$ Quantity of oil required to produce $1 \mathrm{kWh}$ of electricity $(\mathrm{L} / \mathrm{kWh}) ; \mathrm{b}=$ Quantity of oil required to produce $1 \mathrm{~kg}$ of soap $(\mathrm{L} / \mathrm{kg}) ; \mathrm{c}=$ Quantity of electricity produced from total available oil $(\mathrm{kWh}) ; \mathrm{d}=$ Quantity of soap produced from total available oil $(\mathrm{kg})$; $\mathrm{g}=$ Total quantity of oil available annually (L); and 0.6, 1 and 0.7 are fractions of oil, electricity and soap to be sold annually.

\section{Results and Discussion}

\subsection{Technical and Cost Benefit Analysis of Model 1}

This model was built on purchase of seeds from contracted small holder farmers or farmer groups (out-growers) that produce jatropha seeds by means of intercropping in their farms or as hedges. This model also considered the export of jatropha oil and utilisation of press cake for compost. Table 3 presents technical parameters and assumptions considered for the establishment of the out-grower scheme. Based on a required farm size of 200 ha for the base scenario, 400 farmers are required with the assumption that each farmer cultivated or intercropped 0.5 ha of his/her total land holding with jatropha. Planting spacing of $3 \mathrm{~m}$ by $2 \mathrm{~m}$ for intercropping translates into a total of 833 plants for each farmer. A planting distance of $1.5 \mathrm{~m}$ for hedges implies that total planting distance of $556 \mathrm{~m}$ is required for each farmer to achieve the required plant population. Purchase price of seeds at $\$ 0.07 / \mathrm{kg}$ was considered for the base scenario. With annual fruit yield of 4.5 tonnes/ha/year, annual quantities of fruit hulls, crude oil, press cake and residual oil expected to be generated are 306, 183, 387 and 22 tonnes, respectively.

Table 3. Technical parameters and assumptions for out-grower schemes.

\begin{tabular}{cc}
\hline Parameter & Value \\
\hline Cropping model & Intercropping/hedges \\
Planting spacing for intercropping $(\mathrm{m})$ & $3 \mathrm{by} 2$ \\
Area covered per plant $\left(\mathrm{m}^{2}\right)$ & 6 \\
Plant population per hectare & 1667 \\
Total plant population & 333,333 \\
Size of farm for each farmer (ha) & 0.5 \\
Number of plants per farmer & 833 \\
Total number of farmers required & 400 \\
Planting distance for hedges (m) & 1.5 \\
Total planting distance required by each farmer to & 555.6 \\
achieve the required plant population (m) & 0.07 \\
Purchase price of jatropha seeds (kg) (USD) &
\end{tabular}

Farmers that work with jatropha seed cake in the raw form expose themselves to potential risks due to the widely known toxic elements of jatropha that are potentially present in the pressed cake [23]. Composting has been shown to reduce the toxicity and oil content of the press cake [24]. The production and sale of compost from press cake was therefore considered in this model. Table 4 presents assumptions and technical parameters for the compost production. Using a Windrow system and mixing at a ratio of 2:1 of press cake to bulking agents (grass clippings), 290,021 kg of compost 
are expected to be generated from 387 tonnes of press cake annually. A unit price at $\$ 0.17 / \mathrm{kg}$ was considered for revenue generation from the compost.

The cost benefit analysis for this model was considered from two perspectives: processor and small holder farmer. Investment and annual operational cost for the processor were $\$ 78,706$ and $\$ 122,288$ respectively (see Figure 3). Revenue expected to be generated from this model is presented in Figure 4. At a discount rate of $18 \%$, NPV and IRR values for the processor were $\$ 119,504$ and $39.16 \%$, respectively. CBA analysis from the farmers' perspective generated NPV and IRR of \$-88.65 and $7.05 \%$, respectively. This indicates that the purchase price of seeds of $\$ 0.07 / \mathrm{kg}$ produced financial viability for processors but non-viability for the farmer, even with inclusion of revenue from carbon credit (see Table 5).

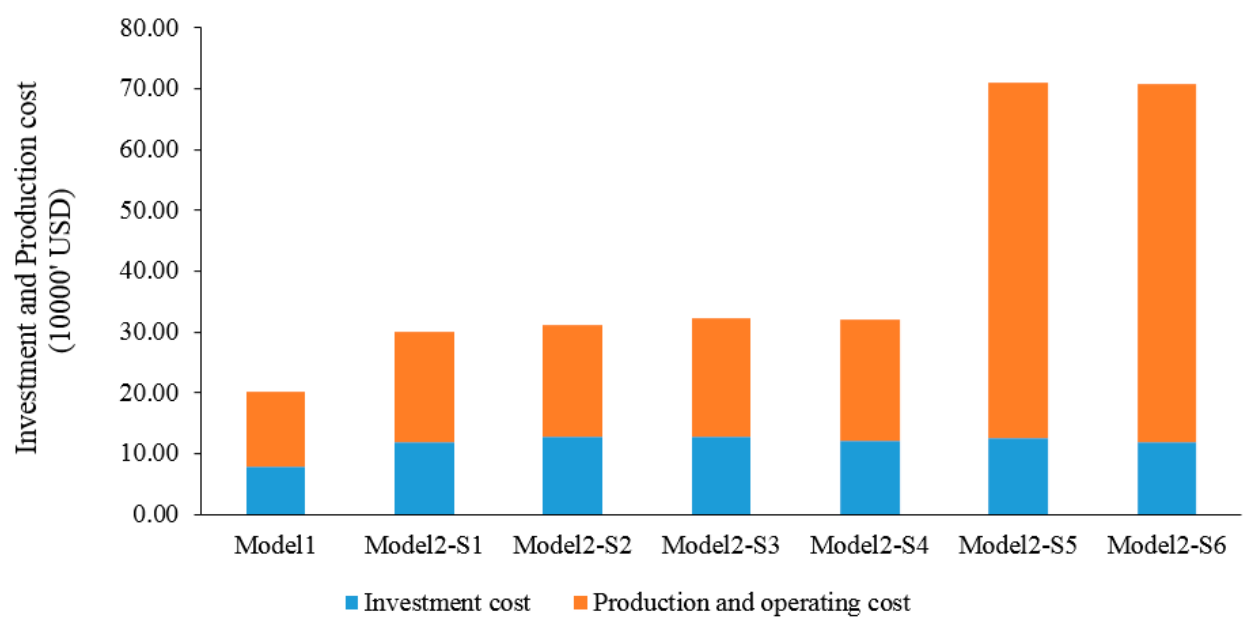

Figure 3. Investment and production cost for models and scenarios.

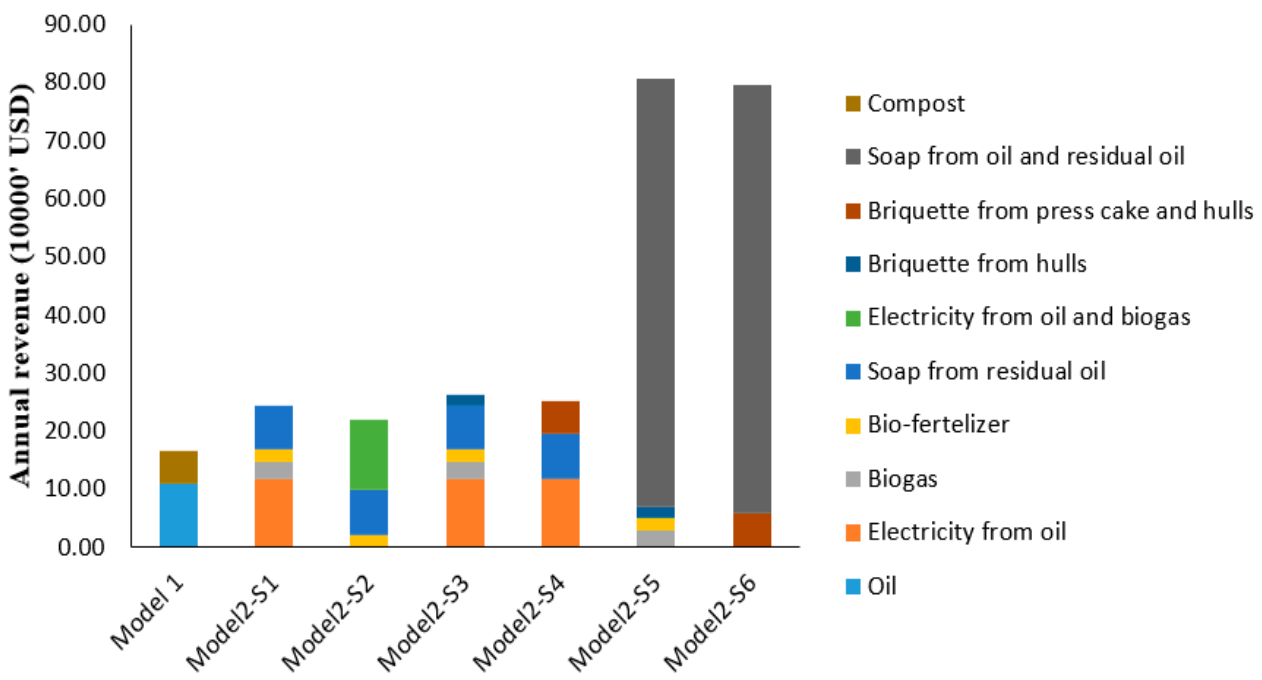

Figure 4. Annual revenues generated from the models and scenarios.

Critical variables identified for sensitivity analysis of this model were discount rate, purchase price of seeds, seed yield and prices of crude oil and compost. Figures 5 and 6 present variation of NPV as discount rate varies from $0 \%$ to $30 \%$ for the processor and farmer, respectively. It indicates that the business venture for the processor is financially viable for the range of discount rates considered. However, financial viability can be achieved if the discount rate is $\leq 7 \%$. Sensitivity analysis on the selling/purchase price of seeds revealed that, at seed price of $\$ 0.05 / \mathrm{kg}$, Model 1 is financially viable for a processor or an investor who buys the seeds from the out-growers but not profitable or viable for 
the farmers engaged as out-growers. The situation is vice versa when the purchase price of seeds is increased to $\$ 0.16 / \mathrm{kg}$ (See Table 6). Moreover, financial viability is achieved at seed purchase price of $\$ 0.1 / \mathrm{kg}$ for both an investor or processor and an out-grower farmer engaged. This translates into NPV and IRR of $\$ 37,185$ and $25.32 \%$, respectively, for the processor while NPV and IRR of $\$ 119$ and 29.65\%, respectively, were realised for the farmer. Even though the Model 1 is not viable for the farmer in the base scenario, increase in seed yield to 7.5 tonnes/ha/year produced positive NPV and IRR. Details of the rest of the sensitivity results for this model are shown in Table 6.

Table 4. Technical parameters and assumptions for compost production.

\begin{tabular}{lc}
\hline \multicolumn{1}{c}{ Parameter } & Value \\
\hline Composting method & Windrow system \\
Quantity of press cake available for composting (tonnes) & 387 \\
Volume of press cake available $\left(\mathrm{m}^{3}\right)$ & 1734 \\
Mixing ratio of press cake to bulking agents (grass clippings) & $2: 1$ \\
Volume of bulking agent required $\left(\mathrm{m}^{3}\right)$ & 867 \\
Total volume of input material $\left(\mathrm{m}^{3}\right)$ & 2601 \\
Quantity of compost generated annually (50\% volume of input & 1301 \\
materials) $\left(\mathrm{m}^{3}\right)$ & 290,021 \\
Quantity of compost generated $(\mathrm{kg})$ & 1 \\
Capacity of sieves (t/h) & 3 \\
Power of motor of sieves (kW) & 290 \\
Operational hours & 870 \\
Electricity consumption (kWh) & 1000 \\
Unit price of sieves (USD) & 10 \\
Unit price of compost thermometer (USD) & 90 \\
Unit price of moisture meter (USD) & 25 \\
Unit price of PH meter (USD) & 40 \\
Number of days for compost to reach maturity & $48-65$ \\
Required temperature ( $\left.{ }^{\circ} \mathrm{C}\right)$ & $50-60$ \\
Moisture content (\% by weight) & $25-35: 1$ \\
C:N ratio & $6.5-8$ \\
PH & 10 \\
Oxygen concentration $(\%)$ & 90 \\
Size of building required for sieving and storage (m $\left.{ }^{2}\right)$ & 0.17 \\
Unit price of compost/kg (USD) & 8.5 \\
Unit price of compost (50 kg bag) (USD) & \\
\hline
\end{tabular}

Table 5. NPV and IRR for the base scenario and sensitivity analysis under Model 1.

\begin{tabular}{ccccc}
\hline \multirow{2}{*}{ Parameter } & \multicolumn{2}{c}{ Model 1-Processor } & \multicolumn{2}{c}{ Model 1-Farmer } \\
\cline { 2 - 5 } & IRR 25 Years (\%) & NPV (\$) & IRR 30 Years & NPV (\$) \\
\hline Base scenario & 39.16 & 119,504 & 7.05 & -88.65 \\
Inclusion of carbon credit & NA & NA & 11.33 & -57.52 \\
\hline
\end{tabular}

Table 6. IRR and NPV for Sensitivity analysis under Model 1.

\begin{tabular}{|c|c|c|c|c|}
\hline \multirow{2}{*}{ Parameter } & \multicolumn{2}{|c|}{ Model 1-Processor } & \multicolumn{2}{|c|}{ Model 1-Farmer } \\
\hline & IRR 25 Years (\%) & NPV (\$) & IRR 30 Years (\%) & NPV (\$) \\
\hline \multicolumn{5}{|c|}{ Selling/purchase price of seeds } \\
\hline USD 0.05 & 47.26 & 174,383 & Negative value * & -227.33 \\
\hline USD 0.16 & Negative value * & $-127,452$ & 60.84 & 535.41 \\
\hline \multicolumn{5}{|c|}{ Price of crude oil } \\
\hline USD $473 /$ tonne & 20.44 & 11,858 & NA & NA \\
\hline USD $1000 /$ tonne & 81.44 & 458,547 & NA & NA \\
\hline
\end{tabular}


Table 6. Cont.

\begin{tabular}{ccccc}
\hline \multirow{2}{*}{ Parameter } & \multicolumn{2}{c}{ Model 1-Processor } & \multicolumn{2}{c}{ Model 1-Farmer } \\
\cline { 2 - 5 } & IRR 25 Years (\%) & NPV (\$) & IRR 30 Years (\%) & NPV (\$) \\
\hline \multicolumn{7}{c}{ Seed yield } \\
\hline 0.55 tonnes/ha/year & NA & NA & Negative value * & -274.69 \\
7.5 tonnes/ha/year & NA & NA & 41.49 & 261.13 \\
\hline & \multicolumn{4}{c}{ Price of compost } \\
\hline USD 0.13 & 25.68 & 39,120 & NA & NA \\
USD 0.25 & 50.81 & 199,889 & NA & NA
\end{tabular}

* No result given in excel model because values are too extreme; NA-Not applicable for the scenario.

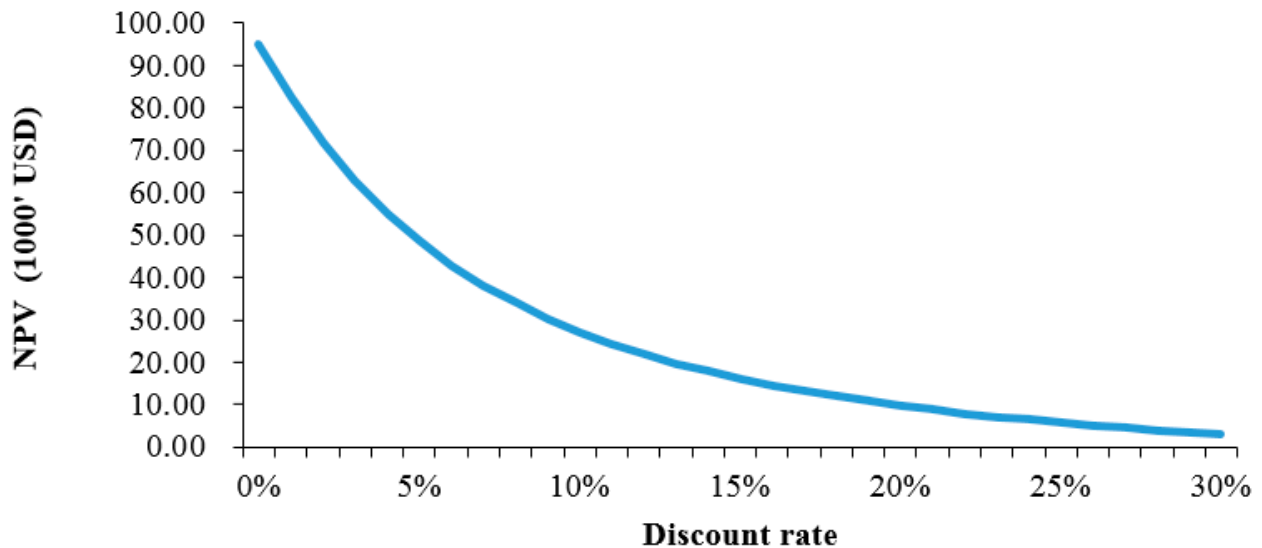

Figure 5. NPV curve for Model 1: Processors' perspective.

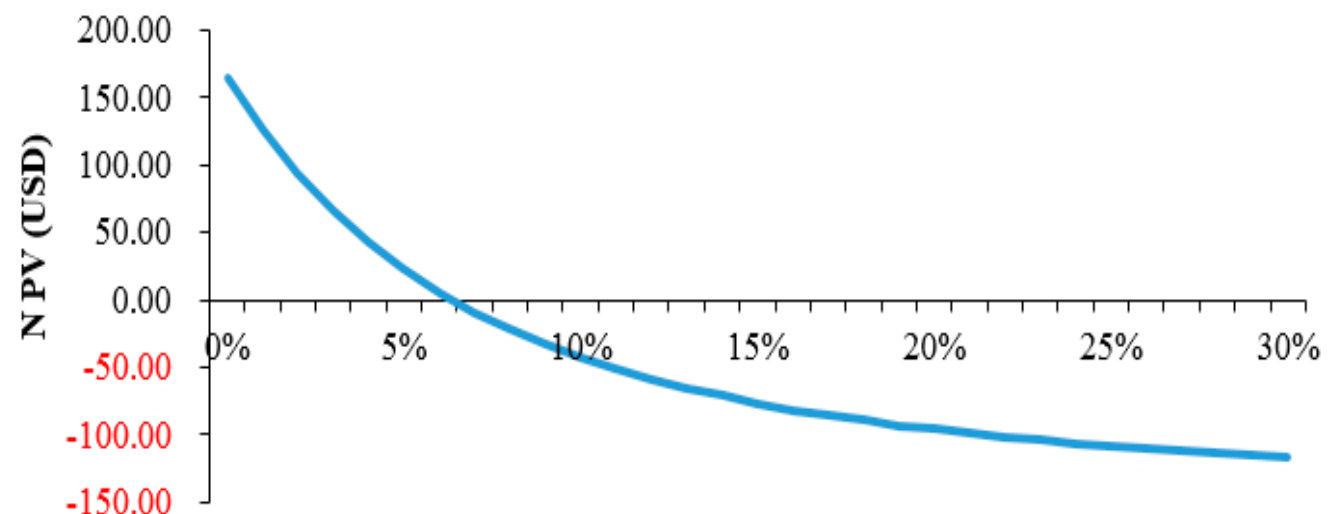

\section{Discount rate}

Figure 6. NPV curve for Model 1: farmers' perspective.

\subsection{Technical and Cost Benefit Analysis of Model 2}

This model builds on Model 1 with the substitution of exporting the crude jatropha oil with local utilisation of the oil and the by-products. The utilisation of the oil for electricity generation and soap production and the by-products for biogas and briquettes production was considered in this model. Six main scenarios under different matrix combinations for oil and by-products utilisation were therefore considered under this model. This has been demonstrated for rural electrification in some Sub-Saharan African countries [25], including some rural communities in Northern Ghana. Five diesel generators of $16 \mathrm{~kW}$ capacity with fuel consumption of $5.4 \mathrm{~L} / \mathrm{h}$ which can run on pure jatropha oil would be required to generate $651,095 \mathrm{kWh}$ of electricity from $219,744 \mathrm{~L}$ of oil annually (see Table 7). 
Feed-in-tariff rate of $\$ 0.18 / \mathrm{kWh}[26]$ was considered for revenue generation from electricity production. The use of jatropha oil for soap production has been reported to be good and safe [8,27]. Model 2 therefore considered the utilisation of the filtered and residual oil for soap production. To produce $1 \mathrm{~kg}$ of soap, $2.77 \mathrm{~L}$ of oil, $2.07 \mathrm{~L}$ of water and $0.41 \mathrm{~kg}$ of caustic soda are required. Annual quantity of soap estimated at $88,756 \mathrm{~kg}$ is expected to be produced from 245,496 L of oil and 36,824 $\mathrm{kg}$ of caustic soda (see Table 8$)$. A unit price of soap bar (180 g) at $\$ 1.5$ was considered for revenue generation.

Table 7. Technical parameters and assumptions for electricity generation.

\begin{tabular}{|c|c|}
\hline Parameter & Value \\
\hline \multicolumn{2}{|l|}{ Electricity generation from jatropha oil } \\
\hline Capacity of generator set @ 50 HZ, 1500 rev/min (kW) & 16 \\
\hline Fuel consumption at $100 \%$ power ratings (litres $/ \mathrm{h}$ ) & 5.4 \\
\hline Quantity of oil available (L) & 219,744 \\
\hline Number of hours generator must operates based on fuel consumption rate & $40,693.41$ \\
\hline Number of generators required assuming operational hours of 8700 annually & 5 \\
\hline Electricity generated $(\mathrm{kWh})$ & 651,095 \\
\hline Unit price of generator (USD) & 4269 \\
\hline Lifespan of generator (years) & 25 \\
\hline Feed in tariff rate (USD/kWh) & 0.18 \\
\hline \multicolumn{2}{|l|}{ Electricity generation from biogas } \\
\hline Generator rated power @ 50 HZ, 1500 rev/min (kW) & 8 \\
\hline Fuel consumption @ 100\% power ratings ( $\left.\mathrm{m}^{3} / \mathrm{kWh}\right)$ & 0.38 \\
\hline Quantity of methane available $\left(\mathrm{m}^{3}\right)$ & 76,888 \\
\hline Electricity generated $(\mathrm{kWh})$ & 29,218 \\
\hline Number of hours generator must operate & 3652.19 \\
\hline Number of generators required & 1 \\
\hline Oil consumption (g/kWh) & 2 \\
\hline Unit price of generator (USD) & 7000 \\
\hline Lifespan of generator (years) & 20 \\
\hline Feed in tariff rate (USD/kWh) & 0.18 \\
\hline Size of building for housing biogas generator $\left(\mathrm{m}^{2}\right)$ & 10 \\
\hline
\end{tabular}

Table 8. Technical parameters and assumptions for soap production.

\begin{tabular}{lc}
\hline \multicolumn{1}{c}{ Parameter } & Value \\
\hline Quantity of oil required to produce 1 kg of soap (litres) & 2.77 \\
Quantity of water required to produce 1 kg of soap (litres) & 2.07 \\
Quantity of caustic soda required to produce 1 kg of soap (kg) & 0.41 \\
Quantity of oil available (tonnes) & 205 \\
Quantity of oil available (litres) & 245,496 \\
Quantity of soap produced from the available oil (kg) & 88,756 \\
Quantity of caustic soda required (kg) & $36,824.44$ \\
Quantity of water required (litres) & 184,122 \\
Unit price of caustic soda per 25 kg (USD) & 300 \\
Capacity of soap mixing tanks (litres) & 98 \\
Number of soap mixing tanks required & 3 \\
Unit price of soap mixing tanks (USD) & 2800 \\
Capacity of manual cutting molds (kg) & 32 \\
Number of hours it takes for soap to harden in molds before removal & 24 \\
Number of manual soap cutting molds required & 12 \\
Unit price of manual soap cutting molds (USD) & 375 \\
Capacity of manual soap cutter per minute (kg) & 1 \\
Number of soap cutters required & 1 \\
Unit price of soap cutter (USD) & 1895 \\
Unit price of bath bomb press (USD) & 275 \\
\hline
\end{tabular}


Table 8. Cont.

\begin{tabular}{lc}
\hline \multicolumn{1}{c}{ Parameter } & Value \\
\hline Unit price of bath bomb molds (USD) & 285 \\
Capacity of drying tray (kg) & 12 \\
Number of hours it takes for soap to cure before packaging (hours) & 336 \\
Number of drying trays required & 270 \\
Unit cost per tray (USD) & 25 \\
Size of building required for soap production $\left(\mathrm{m}^{2}\right)$ & 100 \\
Unit price of soap bar (180 g in weight) (USD) & 1.5 \\
\hline
\end{tabular}

Utilisation of press cake for biogas production was also considered under Model 2. Annual quantities of bio-methane and bio-fertilizer expected to be generated from 387 tonnes of press cake were $80,935 \mathrm{~m}^{3}$ and $106,728 \mathrm{~kg}$, respectively. Two fixed dome digesters of capacity $25 \mathrm{~m}^{3}$ each will be required to hold the press cake generated. Unit price of bio-fertilizer and bio-methane considered for revenue generation were $\$ 0.19 / \mathrm{kg}$ and $\$ 0.39 / \mathrm{m}^{3}$, respectively. Table 9 presents the rest of the technical parameters considered for the biogas production. The use of biogas for electricity generation was also considered. Estimated annual electricity of $29,218 \mathrm{kWh}$ is expected to be generated from $76,888 \mathrm{~m}^{3}$ of biogas. This will require an $8 \mathrm{~kW}$ biogas generator with fuel consumption of $0.38 \mathrm{~m}^{3} / \mathrm{kWh}$ (see Table 7). In situations where the press cake and fruit hulls are used for briquette production, 411 tonnes of briquette are expected to be generated from 693 tonnes of press cake and fruit hulls (see Table 10). Unit price of briquette was assumed to be $\$ 0.12 / \mathrm{kg}$.

Table 9. Technical parameters and Assumptions for biogas production.

\begin{tabular}{lc}
\hline \multicolumn{1}{c}{ Parameter } & Value \\
\hline Digester type & Fixed dome system \\
Density of jatropha press cake $\left(\mathrm{kg} / \mathrm{m}^{3}\right)$ & 1200 \\
Volume of press cake $\left(\mathrm{m}^{3} /\right.$ day) & 0.88 \\
Mixing ratio of press cake and water & $1: 1$ \\
Daily substrate input $\left(\mathrm{m}^{3} /\right.$ day) & 1.77 \\
Retention time $($ days) & 25 \\
Digester volume $\left(\mathrm{m}^{3}\right)$ & 44.14 \\
Required digester volume for optimal gas production $\left(\mathrm{m}^{3}\right)$ & 25 \\
Number of biogas plant required & 2 \\
Operating temperature $\left({ }^{\circ} \mathrm{C}\right)$ & 30 \\
Quantity of total solids available $(\mathrm{Degradable} \mathrm{material)}($ tonnes $)$ & 355.76 \\
Quantity of gas generated (L) $(350 \mathrm{~L} / \mathrm{kgTS})$ & $124,515,468$ \\
Quantity of methane available $(\mathrm{L})(65 \%$ of biogas) & $80,935,054$ \\
Quantity of methane available assuming $5 \%$ losses $(\mathrm{L})$ & $76,888,301$ \\
Quantity of methane available $\left(\mathrm{m}^{3}\right)$ & 76,888 \\
Quantity of digestate generated $(\mathrm{kg})(30 \%$ of feedstock) & 106,728 \\
Cost of Biogas plant per cubic meter (USD) & 300 \\
Lifespan of digester (years) & 25 \\
Unit price of bio methane per cubic meter & 0.39 \\
Unit price of bio fertilizer generated $/ \mathrm{kg}$ & 0.19 \\
\hline
\end{tabular}

The cost-benefit analysis for this model was also done from two perspectives, similar to Model 1: processor and small holder farmer (out-grower). Scenarios 6 and 2 under this model had the lowest and highest investment cost of $\$ 119,160$ and $\$ 128,359$, respectively. Scenarios 1 and 6 had the lowest and highest annual operational cost of $\$ 179,738$ and $\$ 588,033$, respectively (see Figure 3). Investment and operational cost from the farmer's perspective were $\$ 150$ and $\$ 90.81$, respectively. Figure 4 presents streams of revenues generated from each of the scenarios under Model 2. At a discount rate of $18 \%$, all the scenarios under this model had a positive NPV and IRR greater than the interest rate except Scenario 2 (see Table 11). This indicates that all the scenarios under this model are financially viable 
and confirms the assertion by [28] that valorisation of jatropha by-products might fundamentally increase the profitability of jatropha business ventures. Scenario 2 had the lowest NPV and IRR values of $\$ 48,280$ and $23.90 \%$, respectively. Even though all the scenarios considered under this model were financially viable for an investor/processor, financial viability from the perspective of the farmer was not achieved since NPV and IRR values of \$-88.65 and 7.05\% were estimated, respectively.

Table 10. Technical parameters and assumptions for briquette production.

\begin{tabular}{lc}
\hline \multicolumn{1}{c}{ Parameter } & Value \\
\hline Quantity of press cake and hulls available (tonnes) & 693 \\
Capacity of briquette machine (t/h) & 0.18 \\
Operational hours (h) & 1750 \\
Number of briquette machines required & 2 \\
Fraction in weight of cake that remains after compression & 0.6 \\
Quantity of briquettes produced per year (tonnes) & 416 \\
Quantity of briquette assuming 1\% losses (tonnes) & 411 \\
Unit cost of briquette machine (USD) & 1000 \\
Power of motor of briquette machine (kW) & 15 \\
Capacity of carbonizer machine (t/h) & 0.70 \\
Unit price of Carbonizer machine (USD) & 3000 \\
Number of carbonizer machine required & 1 \\
Power of motor of carbonizer (kW) & 1.5 \\
Annual electricity consumption of briquette and carbonizer (kWh) & $60,841.62$ \\
Lifespan of briquette and carbonizer (years) & 20 \\
Oil and lubrication charges (\% of fuel cost) & 2 \\
Size of building required for briquetting (m ${ }^{2}$ ) & 100 \\
unit price per kg of briquette (USD) & 0.12 \\
Unit price per bag of briquette (32 kg) (USD) & 3.84 \\
\hline
\end{tabular}

Critical variables identified for sensitivity analysis of Model 2 were discount rate, selling/purchase price of seeds, seed yield, feed in tariff rate and prices of biogas, bio-fertilizer, briquette and soap. Figure 7 presents variation of NPV as discount rate varies from $0 \%$ to 30\%. It indicates that Scenario 2 is not financially viable at a discount rate $>23.9 \%$ but the rest of the scenarios are financially viable for the range of discount rate considered. Financial viability can be achieved from the perspective of the farmer if the discount rate is $\leq 7 \%$.

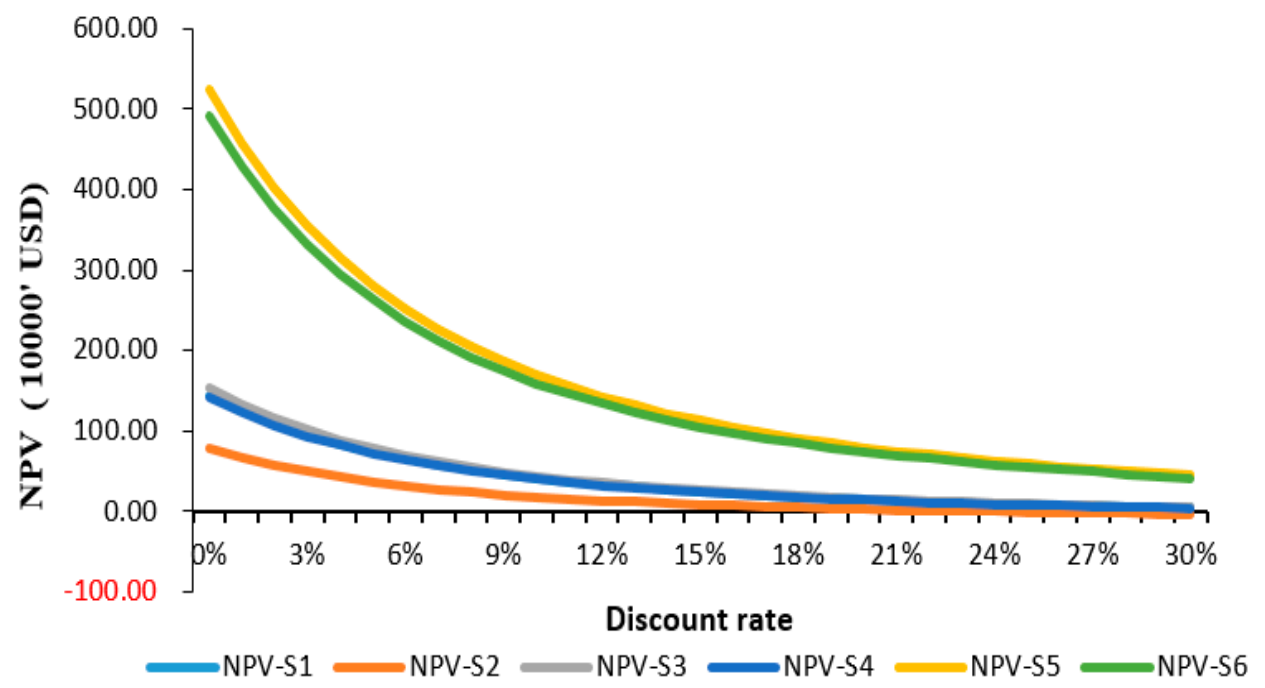

Figure 7. NPV curves for the six scenarios under Model 2. 
Table 11. NPV and IRR for the base scenario and sensitivity analysis for the six scenarios under Model 2.

\begin{tabular}{|c|c|c|c|c|c|c|c|c|c|c|c|c|}
\hline \multirow[b]{2}{*}{ Parameter } & \multicolumn{2}{|c|}{ Scenario 1} & \multicolumn{2}{|c|}{ Scenario 2} & \multicolumn{2}{|c|}{ Scenario 3} & \multicolumn{2}{|c|}{ Scenario 4} & \multicolumn{2}{|c|}{ Scenario 5} & \multicolumn{2}{|c|}{ Scenario 6} \\
\hline & $\begin{array}{c}\text { IRR } 25 \\
\text { Years (\%) }\end{array}$ & NPV (\$) & IRR 25 Years (\%) & NPV (\$) & $\begin{array}{c}\text { IRR } 25 \\
\text { Years (\%) }\end{array}$ & NPV (\$) & $\begin{array}{c}\text { IRR } 25 \\
\text { Years (\%) }\end{array}$ & NPV (\$) & $\begin{array}{c}\text { IRR } 25 \\
\text { Years (\%) }\end{array}$ & NPV (\$) & $\begin{array}{c}\text { IRR } 25 \\
\text { Years (\%) }\end{array}$ & NPV (\$) \\
\hline $\begin{array}{c}\text { Base } \\
\text { Scenario }\end{array}$ & 39.40 & 184,768 & 23.90 & 48,281 & 39.10 & 193,654 & 37.34 & 172,668 & 92.75 & 907,230 & 91.62 & 847,265 \\
\hline \multicolumn{13}{|c|}{ Sensitivity analysis } \\
\hline \multicolumn{13}{|c|}{ Purchase price of seeds $/ \mathrm{kg}$} \\
\hline USD 0.05 & 44.78 & 239,647 & 29.98 & 103,160 & 44.18 & 248,533 & 42.63 & 227,547 & 96.04 & 962,109 & 95.10 & 902,144 \\
\hline USD 0.16 & 8.19 & $-62,188$ & Negative value * & $-198,675$ & 10.37 & $-53,302$ & 6.74 & $-74,288$ & 76.89 & 660,274 & 74.78 & 600,309 \\
\hline \multicolumn{13}{|c|}{ Price of biogas $/ \mathrm{m}^{3}$} \\
\hline USD 0.27 & 34.99 & 142,146 & NA & NA & 34.95 & 151,032 & NA & NA & 90.14 & 864,608 & NA & NA \\
\hline USD 0.51 & 43.60 & 227,389 & NA & NA & 43.07 & 236,276 & NA & NA & 95.31 & 949,851 & NA & NA \\
\hline \multicolumn{13}{|c|}{ Price of bio fertilizer $/ \mathrm{kg}$} \\
\hline USD 0.13 & 36.29 & 154,482 & 20.28 & 17,995 & 36.17 & 163,368 & NA & NA & 90.90 & 876,944 & NA & NA \\
\hline USD 0.25 & 42.27 & 213,645 & 27.17 & 77,158 & 41.81 & 222,531 & NA & NA & 94.49 & 936,1066 & NA & NA \\
\hline \multicolumn{13}{|c|}{ Price of briquette $/ \mathrm{kg}$} \\
\hline USD 0.08 & NA & NA & NA & NA & 36.40 & 165,666 & 28.05 & 83,967 & 91.04 & 879,241 & 85.81 & 758,564 \\
\hline USD 0.16 & NA & NA & NA & NA & 41.73 & 221,642 & 45.75 & 261,368 & 94.44 & 935,218 & 97.20 & 935,965 \\
\hline \multicolumn{13}{|c|}{ Feed-in-tariff rate(kWh) } \\
\hline USD 0.23 & 53.25 & 332,669 & 39.91 & 202,819 & 52.19 & 341,555 & 50.99 & 320,569 & NA & NA & NA & NA \\
\hline \multicolumn{13}{|c|}{ Price of soap $/ 180 \mathrm{~g}$} \\
\hline USD 1.1 & 28.86 & 86,710 & 10.94 & $-49,888$ & 29.21 & 95,596 & 27.00 & 74,610 & 17.48 & $-3,893$ & 7.78 & $-63,858$ \\
\hline USD 1.95 & 49.43 & 289,805 & 35.12 & 153,207 & 48.58 & 298,691 & 47.22 & 277,705 & 145.3 & $1,932,243$ & 146.7 & $1,872,278$ \\
\hline
\end{tabular}


Sensitivity analysis on the selling/purchase price of seeds revealed that, at seed price of $\$ 0.05 / \mathrm{kg}$, the projects are financially viable from the processors perspective for all the scenarios but not viable for farmer engaged as out-growers. The situation is vice versa when the purchase price of seeds was increased to $\$ 0.16 / \mathrm{kg}$. Under this given seed price, only Scenarios 5 and 6 were considered to portray financially viability (see Table 11). Financial viability for both an investor/processor and a farmer was achieved when the purchase $/$ selling price of seeds was $\$ 0.085 / \mathrm{kg}$ translating into a positive NPV for all the scenarios. A decrease in the price of soap to $\$ 1.1 / 180$ g generated a negative NPV and IRR $<25 \%$ for Scenarios 2, 5 and 6, since the bulk of the revenues for these scenarios were generated from the sale of soap.

\subsection{Cost Benefit Analysis for Utilisation of Jatropha Oil}

The models were built on a common farming model, which is an out-grower farming scheme. As described earlier, three cases were considered for the utilisation of jatropha oil under these models; export, electricity and soap production. This section of the study therefore sought to identify which of the cases of oil utilisation is financially viable and profitable under this farming model from the perspective of an investor/processor.

Utilisation of the oil for electricity production had the highest investment cost of $\$ 95,303$ whereas soap production had the highest annual production cost of $\$ 496,402$ (see Figure 8). The cost of producing a litre of jatropha oil was estimated at $\$ 0.48$. This is lower than reported figures of $\$ 0.61-1.04 / \mathrm{L}$ [29]. The difference can be attributed to lower cost of labour and production cost in Ghana. Soap and electricity production had the highest and lowest unit profit of 1.96/ kg and $0.01 / \mathrm{kWh}$ respectively (see Figure 9). Unit profit for export of oil was determined to be $\$ 0.03 / \mathrm{L}$. The findings are lower than the reported profit of $\$ 0.21 / \mathrm{L}$ [18]. At a discount rate of $18 \%$, NPV values for export, electricity and soap production under the out-grower farming scheme were estimated to be $\$-19,697, \$-43,209$ and $\$ 653,940$ respectively. This indicates that utilisation of jatropha oil for soap production is the only profitable case for oil utilisation under the out-grower farming schemes. This confirms the assertion by [5] that utilisation of jatropha oil for soap making is the most profitable venture. The study further revealed that export of oil and electricity production is only profitable at oil price $\geq \$ 624 /$ tonne and feed-in-tariff rate $\geq \$ 0.20 / \mathrm{kWh}$.

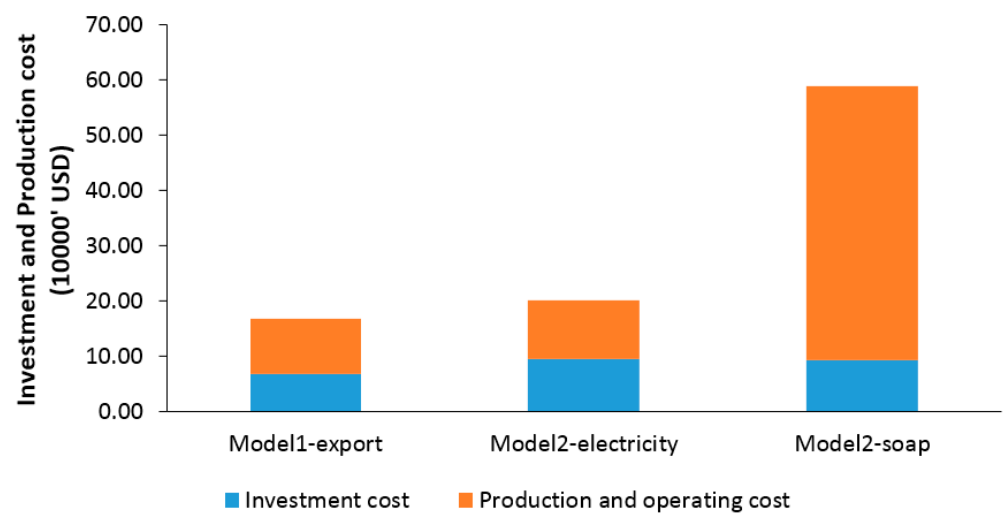

Figure 8. Investment and production cost for utilisation of oil.

\subsection{Optimisation of Jatropha Oil and By-Products Utilisation}

Three main cases for jatropha oil utilisation were considered in the developed models. This section of the study sought to optimise their use through profit maximisation. This was performed by taking into consideration the resources and amount of raw material used in the production of each unit, market availability and unit profit of each product as determined from the models. Table 12 presents the objective functions and constraints used in the optimisation of the oil. 


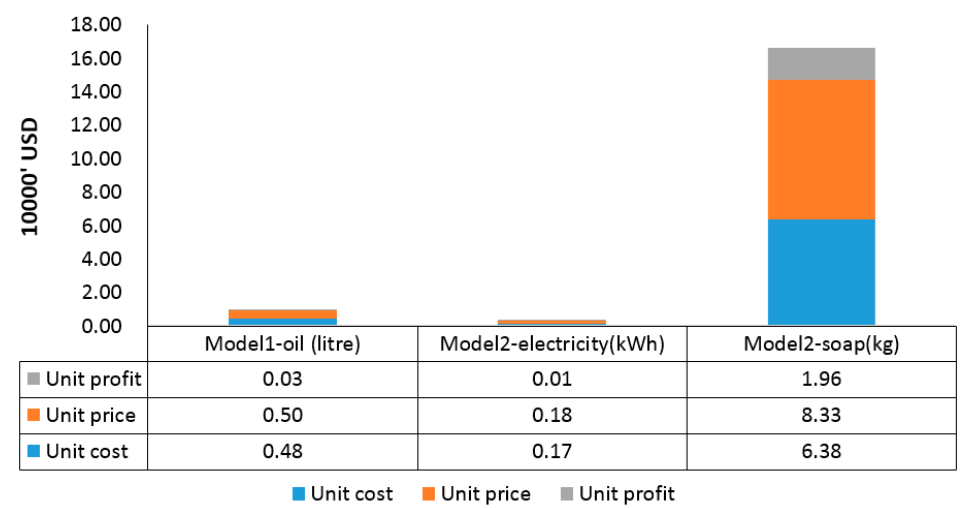

Figure 9. Unit price, cost and profit for utilisation of oil under the models.

Table 12. Objective function and constraints for the optimization.

\begin{tabular}{|c|c|}
\hline Objective Function & Constraints \\
\hline \multicolumn{2}{|c|}{ Utilisation of Oil } \\
\hline $\begin{array}{l}\quad Z_{1}=\text { Maximize }(P)=0.03 X_{1}+0.01 X_{2}+1.96 X_{3} \\
\text { where: } \\
X_{1}=\text { Quantity of oil required for export }(\mathrm{L}) \\
X_{2}=\text { Quantity of electricity required }(\mathrm{kWh}) \\
X_{3}=\text { Quantity of soap required }(\mathrm{kg}) \\
P=\text { Maximum profit (USD) }\end{array}$ & $\begin{array}{l}C_{1}: X_{1}+0.34 X_{2}+2.77 X_{3} \leq 219,744.43 L \\
C_{2}: X_{1} \leq 131,846.66 \mathrm{~L} \\
C_{3}: X_{2} \leq 651,094.61 \mathrm{kWh} \\
C_{4}: X_{3} \leq 62,129.45 \mathrm{~kg} \\
C_{5}: X_{1}, X_{2}, X_{3} \geq 0\end{array}$ \\
\hline
\end{tabular}

Solving the linear equation using Simplex method yielded a maximum annual profit of $\$ 123,300$. This required the production of 140,135 kWh of electricity and $62,129 \mathrm{~kg}$ of soap and export of none of the oil. Performing sensitivity analysis on the linear equation by increasing price of oil to $\$ 1000 /$ tonne yielded a maximum profit of $\$ 138,726$. This can be achieved at a projected export of $47,646 \mathrm{~L}$ of jatropha oil and production of $62,129 \mathrm{~kg}$ of soap. Decreasing the price of soap to $\$ 1.1 / 180 \mathrm{~g}$ generated a maximum profit of $\$ 7410$ by producing $646,307 \mathrm{kWh}$ of electricity. Purchase price of seeds is a very critical parameter in the models developed. Increasing the purchase price of seeds to $\$ 0.1 / \mathrm{kg}$ (recommended price as determined in the models) yielded a maximum profit of $\$ 109,129$ which can be achieved by producing $62,129 \mathrm{~kg}$ of soap without export of the oil or its use for electricity generation.

\section{Conclusions}

The aim of this study was to develop techno-economic models for the production and optimised utilisation of jatropha oil and by-products under an out-grower farming scheme. The findings revealed that Model 1 was financially viable for an investor/processors' but not for a farmer engaged as an out-grower to cultivate and supply jatropha seeds at seed price of $\$ 0.07 / \mathrm{kg}$. Financial viability was, however, achieved under Model 1 for both parties at seed price of $\$ 0.1 / \mathrm{kg}$. All scenarios considered under Model 2 were financially viable for an investor/processor to the disadvantage of the farmer at seed price of $\$ 0.07 / \mathrm{kg}$. Financial viability was, however, achieved for both the processor and farmer at a seed price of $\$ 0.085 / \mathrm{kg}$. The findings indicate that valorisation of jatropha by-products and local utilisation of oil produce financial viability for jatropha production and processing ventures. The models are, however, sensitive to seed yield, market prices of crude jatropha oil, soap, biogas, compost, electricity and briquette. Utilisation of the oil for soap production was identified to be the only profitable case for oil utilisation in the base scenario in terms of NPV and IRR. However, export of the oil and its use for electricity production can only be profitable at oil price $\geq \$ 624 /$ tonne and feed-in-tariff rate $\geq \$ 0.20 / \mathrm{kWh}$, respectively. Optimising the utilisation of the oil resulted in an annual maximum profit of $\$ 123,300$. This will be achieved at the production of $140,135 \mathrm{kWh}$ of electricity and $62,129 \mathrm{~kg}$ of soap without the need to export any amount of the oil produced. The findings of the study 
indicate that jatropha production and utilization is not all gloomy as reported but with the adoption of the right business models in this study, it can provide sound economic benefits for both processors and farmers. The adaptation of these models can ensure sustainable production and utilization of Jatropha oil and by-products.

Author Contributions: I.O. conceived of the study, drafted the manuscript and participated in the sequence alignment. J.O.A. was involved in data analysis and contributed in the drafting of the manuscript. F.K. was involved in data analysis and participated in the drafting of the manuscript and in the sequence alignment. All authors read and approved the final manuscript.

Conflicts of Interest: The authors declare no conflict of interest.

\section{Appendix A. References for Technical Parameters, Assumptions and Cost Components Used in the Models}

\begin{tabular}{|c|c|c|}
\hline Parameter & Value & References \\
\hline \multicolumn{3}{|c|}{ Plantation establishment } \\
\hline Planting spacing & $\begin{array}{l}2 \mathrm{~m} \text { by } 2 \mathrm{~m} \text { for jatropha plantation and } 1.5 \mathrm{~m} \text { within } \\
\text { rows for jatropha hedges }\end{array}$ & {$[11,30]$} \\
\hline Lifespan of jatropha plantation & $30-50$ years & [31] \\
\hline Production start time (economic yield) & 3 years & [4] \\
\hline Plant yield per ha & $\begin{array}{l}\text { minimum } 0.55 \text {, average } 3 \text { and maximum } 7.5 \text { tonnes } \\
\text { per ha }\end{array}$ & {$[4,5,32-37]$} \\
\hline \multicolumn{3}{|c|}{ Small-holder farmers (seed production) } \\
\hline $\begin{array}{l}\text { Labour requirement for land preparation, planting } \\
\text { weeding and pruning, harvesting and dehulling }\end{array}$ & - & {$[29,37]$} \\
\hline Labour requirement for harvesting & $40 \mathrm{~kg}$ of seeds per person per day & [4] \\
\hline Cost for dehulling & $10 \%$ of harvesting cost & [4] \\
\hline Cost of labour per day & USD 7.2 & [38] \\
\hline Purchase price of seeds per $\mathrm{kg}$ & $\begin{array}{l}\text { Minimum USD 0.05, average USD } 0.07 \text { and } \\
\text { maximum of USD } 0.16\end{array}$ & [19] \\
\hline \multicolumn{3}{|c|}{ General information } \\
\hline Fuel cost per litre & USD 0.99 & [39] \\
\hline Electricity cost per $\mathrm{kWh}$ & USD 0.15 & [26] \\
\hline Cost of building per square meter & USD 90 & [40] \\
\hline Wages of workers & $\begin{array}{l}\text { Calculated from daily minimum wage in } \\
\text { Ghana-USD } 2\end{array}$ & [41] \\
\hline \multicolumn{3}{|c|}{ Oil extraction } \\
\hline $\begin{array}{l}\text { Percentage composition of jatropha seeds, hulls, oil, } \\
\text { press cake and residual oil }\end{array}$ & $66 \%, 34 \%, 30.89 \%, 65.1 \%$ and $3.60 \%$ respectively & [38] \\
\hline Price and technical parameters of jatropha de-huller & - & [42] \\
\hline Price and technical parameters of oil screw press & - & [43] \\
\hline Price and technical parameters of filtering unit & - & \\
\hline Selling price of crude jatropha oil per tonne & Minimum 473 average 600 Maximum 1000 & {$[11,44]$} \\
\hline
\end{tabular}




\begin{tabular}{|c|c|c|}
\hline \multicolumn{3}{|c|}{ Biogas production } \\
\hline Density of jatropha press cake & $1200 \mathrm{~kg} / \mathrm{m}^{3}$ & [45] \\
\hline Sizing of biogas digester & & [46] \\
\hline Unit cost of digester per cubic meter & 300 & [38] \\
\hline Quantity of gas generated from press cake & $\begin{array}{l}\text { Press cake consist of } 92 \% \text { oTS and biogas generated } \\
\text { is } 350 \mathrm{~L} / \mathrm{KgoTS} \text { with } 65 \% \text { methane }\end{array}$ & [47] \\
\hline Quantity of digestate generated & $30 \%$ of feedstock & [48] \\
\hline Price of bio-methane per cubic meter & $\begin{array}{l}\text { Calculated from the relation that } 1 \mathrm{~m}^{3} \text { of biogas is } \\
\text { proportional to } 0.6 \mathrm{~m}^{3} \text { of LPG gas, current price of } \\
\text { LPG gas per kg USD } 0.86 \text { price of biogas is USD } \\
0.39 \text { per } \mathrm{m}^{3}\end{array}$ & {$[38,46]$} \\
\hline Price of bio-fertilizer kg & $\begin{array}{l}\text { Price of bio-fertilizer is assumed to be } 1 / 3 \text { price of } \\
\text { chemical fertilizer which is } 100 \text { Cedis per } 50 \mathrm{~kg} \text { bag }\end{array}$ & [38] \\
\hline \multicolumn{3}{|c|}{ Briquette production } \\
\hline Price and technical parameters of briquette machine & & [49] \\
\hline $\begin{array}{l}\text { Price and technical parameters of } \\
\text { carbonizing machine }\end{array}$ & & [50] \\
\hline Fraction of cake that remains after compression & 0.6 & [51] \\
\hline Unit price per $\mathrm{kg}$ of briquette & $\begin{array}{l}\text { USD } 0.12 \text { (calculated from average price of wood } \\
\text { charcoal in Ghana) }\end{array}$ & [52] \\
\hline \multicolumn{3}{|c|}{ Electricity generation } \\
\hline $\begin{array}{l}\text { Price and technical parameters of jatropha } \\
\text { oil generator }\end{array}$ & & [53] \\
\hline Price and technical parameters of biogas generator & & [54] \\
\hline Feed in tariff rate & USD 0.18 & [55] \\
\hline \multicolumn{3}{|c|}{ Soap production } \\
\hline $\begin{array}{l}\text { Quantity of oil, caustic soda and water required to } \\
\text { produce } 1 \mathrm{~kg} \text { of soap }\end{array}$ & $2.77 \mathrm{~L}, 0.41 \mathrm{~kg}$ and 2.07 litters respectively & {$[30,56]$} \\
\hline Price and technical parameters of soap mixing tanks & & [57] \\
\hline Price of caustic soda per $25 \mathrm{~kg}$ & USD 300 & [58] \\
\hline Price of manual cutting moulds ( $32 \mathrm{~kg}$ capacity) & USD 375 & [59] \\
\hline Price of soap manual cutter & USD 1895 & [60] \\
\hline Price of bath bomb press and moulds & USD 275 and 285 respectively & [61] \\
\hline Unit price of drying trays (12 kg capacity) & USD 25 & [62] \\
\hline Period for curing & two weeks & [30] \\
\hline Unit price of soap per $180 \mathrm{~g}$ & 1.5 USD & [38] \\
\hline \multicolumn{3}{|c|}{ Compost production } \\
\hline $\begin{array}{l}\text { Percentage volume of input materials that remains } \\
\text { after composting }\end{array}$ & $50 \%$ & [63] \\
\hline Ratio of press cake to bulking agent & $2: 1$ & [64] \\
\hline $\begin{array}{l}\text { Conditions for optimal compost production: } \\
\text { temperature, moisture content, } \mathrm{C}: \mathrm{N} \text { ratio, } \mathrm{PH} \text { and } \\
\text { oxygen concentration }\end{array}$ & $\begin{array}{l}48-65{ }^{\circ} \mathrm{C}, 50 \%-60 \%, 25-35: 1,6.5-8 \text { and } 10 \% \\
\text { respectively }\end{array}$ & {$[63,65]$} \\
\hline $\begin{array}{l}\text { Price and technical parameters of compost } \\
\text { screen sieves }\end{array}$ & USD 1000 & [66] \\
\hline $\begin{array}{l}\text { Price of monitoring devices (compost thermometer, } \\
\text { ph meters and moisture meter) }\end{array}$ & USD 125 & [67] \\
\hline
\end{tabular}

Exchange rate of GHф3.5 to 1 USD was used.

\section{References}

1. Energy Commission. Draft Bioenergy Policy of Ghana. 2010. Available online: http://cleancookstoves.org/ resources_files/draft-bioenergy-policy-for.pdf (accessed on 15 June 2015). 
2. Kemausuor, F.; Nygaard, I.; Mackenzie, G. Prospects for bioenergy use in Ghana using Long Range Energy Alternative Planning model. Energy 2015, 93, 672-682. [CrossRef]

3. Kumar, A.; Sharma, S. An evaluation of multipurpose oil seed crop for industrial uses (Jatropha curcas L.): A review. Ind. Crops Prod. 2008, 28, 1-10. [CrossRef]

4. Van Dorp, M. Economic Feasibility of Jatropha Production and Processing: A calculation Model for Business Case Development by Small Producer Organizations (SPO). 2013. Available online: http://www.jatropha. pro/PDF\%20bestanden/5.\%20Annex\%20-\%20Economic\%20feasibility\%20of\%20Jatropha.pdf (accessed on 10 June 2015).

5. Openshaw, K. A review of Jatropha curcas: An oil plant of unfulfilled promise. Biomass Bioenergy 2000, 19, 1-15. [CrossRef]

6. Kywe, T.T.; Oo, M.M. Production of biodiesel from Jatropha oil (Jatropha curcas) in pilot plant. Proc. World Acad. Sci. Eng. Technol. 2009, 38, 481-487.

7. Sheehan, J.; Camobreco, V.; Duffield, J.; Graboski, M.; Shapouri, H. Life Cycle Inventory of Biodiesel and Petroleum Diesel for Use in an Urban Bus. Available online: http:/ /www.nrel.gov/docs/legosti/fy98/24089. pdf (accessed on 2 August 2015).

8. Vollner, T. Safety Evaluation of the Cosmetic Product "Pure Jatropha Soap" and Its Effects on Human Health. 2011. Available online: http://www.jatropha.pro/PDF\%20bestanden/sb_pure_jatropha_soap_engl.pdf (accessed on 25 July 2015).

9. Food and Agriculture Organization of the United Nations (FAO). Jatropha: A Smallholder Bioenergy Crop: The Potential for Pro-Poor Development. 2010. Available online: http://www.fao.org/docrep/012/i1219e/ i1219e.pdf (accessed on 10 June 2015).

10. Achten, W.; Maes, W.; Aerts, R.; Verchot, L.; Trabucco, A.; Mathijs, E.; Singh, V.; Muys, B. Jatropha: From global hype to local opportunity. J. Arid Environ. 2009, 74, 164-165. [CrossRef]

11. Wahl, L.T.; Hildebrandt, C.; Moser, F.; Lüdeke-Freund, K.; Averdunk, R.; Bailis, K.K. Insights into Jatropha Projects Worldwide: Key Facts \& Figures from a Global Survey; Leuphana Universität: Lüneburg, Germany, 2012.

12. Sawe, E.; Shuma, J. Socio-economic experiences of Different Jatropha Business Model in Africa. In Socio-Economic Impacts of Bioenergy Production, 2nd ed.; Rutz, D., Janssen, R., Eds.; Springer: Cham, Switzerland; Heidelberg, Germany; New York, NY, USA; Doredrecht, The Netherlands; London, UK, 2014; Volume 1, pp. 67-90.

13. Ofori-Boateng, C.; Lee, K.T. Feasibility of Jatropha oil for biodiesel: Economic Analysis. In Proceedings of the World Renewable Energy Congress, Linkoping, Sweden, 18-13 May 2011.

14. Romijn, H.; Heijnen, S.; Colthoff, J.M.; Jong, B.D.; Eijck, J.V. Economic and Social Sustainability Performance of Jatropha Projects: Results from Field Surveys in Mozambique, Tanzania and Mali. Sustainability 2014, 6, 6203-6235. [CrossRef]

15. Brüntrup, M.; Swetman, T.; Michalscheck, M.; Asante, F. Factors of Success and Failure of Large Agro-Enterprises (Production, Processing and Marketing), A Pilot Study in Ghana Results of Case Studies in the Fruit, Maize, and Palm Oil Sub-Sectors. 2013. Available online: http://www.diegdi.de/uploads/media/ Reprint-Factors_of_Success_and_Failure.pdf (accessed on 25 November 2014).

16. Boamah, F. Imageries of the contested concepts "land grabbing" and "land transactions": Implications for biofuels investments in Ghana. Geoforum 2014, 54, 324-334. [CrossRef]

17. Van Eijck, J.; Rom Colthoff, J.; Romijn, H.; Heijnen, S.; de Ruijter, F.; Jongschaap, R. Jatropha Sustainability Assessment, Data from Tanzania, Mali \& Mozambique; NL Agency: Utrecht, The Netherlands, 2013; p. 101.

18. FACT Foundation. Jatropha, retrospective and future development. In Proceedings of the Jatropha Conference, Groningen, The Netherlands, 1-2 November 2010.

19. Van Eijck, J.V.; Smeets, E.; Romijn, H.; Balkema, A.; Jongschaap, R. Jatropha Assessment-Agronomy, Socio-Economic Issues, and Ecology. Available online: http://english.rvo.nl/sites/default/files/2013/12/ Report\%20Jatropha\%20assessment\%20-\%20Copernicus\%20-\%20NPSB.pdf (accessed on 5 August 2014).

20. Ghana Statistical Service (GSS). Ghana's Inflation Rate. Available online: http:/ /www.statsghana.gov.gh/ (accessed on 26 June 2015).

21. Bank of Ghana (BoG). Daily Interest Rate. Available online: http://www.bog.gov.gh/index.php?option= comwrapper\&view=wrapper\&Itemid=255 (accessed on 26 June 2015).

22. Sidho, H.S.; Singh, S.; Ahuja, S. Optimisation of energy use in different crop production systems. J. Agric. 2004, 85, 50-55. 
23. Barbee, M.J. Preliminary Investigation of the Risks Associated with Applying Non-composted Jatropha Curcas Seed Cake as a Fertilizer; Masters Project Report Environmental Engineering; University of Colorado Boulder: Boulder, CO, USA, 2012.

24. Chaturvedi, S.; Kumar, A. Bio-diesel waste as tailored organic fertilizer for improving yields and nutritive values of Lycopercicum esculatum (tomato) crop. J. Soil Sci. Plant Nutr. 2012, 12, 801-810. [CrossRef]

25. Dimpl, E.; Blunck, M. Small-Scale Electricity Generation from Biomass Part III: Vegetable Oil, GIZ-HERA—Poverty-oriented Basic Energy Services, 1st ed.; GIZ-HERA: Eschborn, Germany, 2011.

26. Public Utility Regulatory Commission (PURC). Approved Electricity Tariffs in Ghana. 2014. Available online: http://gbcghana.com/kitnes/data/2013/12/23/1.1644223.pdf (accessed on 15 August 2015).

27. Holl, M.A.; Gush, M.B.; Hallowes, J.; Versfeld, D.B. Jatropha curcas in South Africa: An Assessment of its Water Use and Bio-Physical Potential. WRC Report No 1497/1/07. Available online: http:/ /jatropha.pro/ PDF\%20bestanden/JatrophaWater\%20South\%20Africa.pdf (assessed on 2 July 2015).

28. Soto, I.; Feto, A.; Keane, J. Are Jatropha and Other Biofuels Profitable in Africa? Available online: http://www.cde.unibe.ch/unibe/portal/fak_naturwis/g_dept_kzen/b_cde/content/e65013/e85096/ e100920/e133161/e187335/pane187341/e187345/files187349/BIA_policy_brief_profitability_eng.pdf (accessed on 27 January 2015).

29. Van Eijck, J.V.; Smeete, E.; Faaij, A. Jatropha, A promising crop for Africa's Biofuel Production? In Socio-Economic Impacts of Bioenergy Production, 2nd ed.; Rutz, D., Janssen, R., Eds.; Springer: Cham, Switzerland; Heidelberg, Germany; New York, NY, USA; Doredrecht, The Netherlands; London, UK, 2014; Volume 1, pp. 27-40.

30. Mawire, B. Biofuels and Economic Welfare a Cost-Benefit Analysis of Jatropha Schemes in Zimbabwe; Institute of Development Research and Development Policy: Bochum, Germany, 2008; Volume 186.

31. Singh, R.N.; Vyas, D.K.; Srivastava, N.S.L.; Narra, M. SPERI experience on holistic approach to utilise all parts of Jatropha curcas fruit for energy. Renew. Energy 2008, 33, 1868-1873. [CrossRef]

32. Francis, G.; Edinger, R.; Becker, K. A concept for simultaneous wasteland reclamation, fuel production, and socio-economic development in degraded areas in India: Need, potential and perspectives of Jatropha plantations. Nat. Resour. Forum 2005, 29, 12-24. [CrossRef]

33. Heller, J. Physic nut, Jatropha curcas L. In Promoting the Conservation and Use of Underutilised and Neglected Crops; Institute of Plant Genetics and Crop Plant Research: Gatersleben, Germany; International Plant Genetic Resources Institute: Rome, Italy, 1996.

34. Achten, W.M.J.; Verchot, L.; Franken, Y.J.; Mathijs, E.; Singh, V.P.; Aerts, R.; Muys, B. Jatropha biodiesel production and use. Biomass Bioenergy 2008, 32, 1063-1084. [CrossRef]

35. Ghosh, A.; Patolia, J.S.; Chaudhary, D.R.; Chikara, J.; Rao, S.N.; Kumar, D. Response of Jatropha curcas under Different Spacing to Jatropha De-Oiled Cake, in FACT Seminar on Jatropha curcas L. Agronomy and Genetics; Article No. 8; Wageningen FACT Foundation: Wageningen, The Netherlands, 2007.

36. Jongschaap, R.; Corré, W.; Bindraban, P.; Brandenburg, W. Claims and Facts on Jatropha curcas L. Global Jatropha curcas Evaluation, Breeding and Propagation Programme; Plant Research International BV: Wageningen, The Netherlands, 2007.

37. Deutsche Gesellschaft für Technische Zusammenarbeit (GTZ). Jatropha Reality Check: A Field Assessment of the Agronomic and Economic Viability of Jatropha and Other Oilseed Crops in Kenya. 2009. Available online: http:/ / www.worldagroforestry.org/downloads/Publications/PDFS/B16599.pdf (accessed on 3 June 2015).

38. Osei, I. Development of Techno-Economic Models for Optimized Utilization of Jatropha Curcas Linnaeus. Master's Thesis, Kwame Nkrumah University of Science and Technology, Kumasi, Ghana, 2016.

39. National Petroleum Authority (NPA). Fuel Prices in Ghana. Available online: http://npa.gov.gh/npa_new / index.php (accessed on 1 September 2015).

40. Ghana Statistical Service (GSS). Prime Building Cost Index (CPI). 2011. Available online: http://www. statsghana.gov.gh/docfiles/news/prime_building_costs_index(pbci)_jan2000sept2011_P3_2011nov30.pdf (accessed on 13 September 2015).

41. Daily Minimum Wage in Ghana. Available online: http://www.myjoyonline.com/business/2015/January20th/minimum-wage-increased-by-ghc1.php (accessed on 12 August 2015).

42. Prices of Dehuller. Available online: http://www.alibaba.com/product-detail/Dehuller_552004548.html (accessed on 15 August 2015). 
43. Jatropha Oil Crushers, including FACT Information. Available online: http://www.jatropha.pro/jatropha_ oil_expellers.htm (accessed on 25 August 2015).

44. Jatropha World. Economics of Jatropha Oil Production. 2013. Available online: http://www. jatrophabiodiesel.org/extraction.php (accessed on 25 August 2015).

45. Lestari, D.; Mulder, W.; Weusthuis, R.; Sanders, J. Jatropha Protein Products for Technical Applications. 2008. Available online: http://jatropha.pro/PDF\%20bestanden/Wageningen\%20U.pdf (accessed on 4 September 2015).

46. Ananthakrishnan, R.; Sudhakar, K.; Abhishek, G.; Sravan, S.S. Economic Feasibility of Substituting LPG with Biogas for MANIT Hostels. Int. J. ChemTech Res. 2013, 5, 891-893.

47. Stelyus, L.; Mkoma, F.; Mabiki, P. Jatropha as energy potential biofuel in Tanzania. Int. J. Environ. Sci. 2012, 2, 1553-1564. [CrossRef]

48. Staubmann, R.; Foidl, G.; Foidl, N.; Gubitz, G.M.; Lafferty, R.M.; Arbizu, V.M.; Steiner, W. Biogas production from jatropha press cake. Appl. Biochem. Biotechnol. 1997, 63-65, 457-467. [CrossRef] [PubMed]

49. Biomass charcoal briquettes. Available online: http://www.alibaba.com/product-detail/barbecuecharcoal-machine-biomass-charcoal-briquette_1342594014.html?spm=a2700.7724857.35.1.I3lhLC (accessed on 11 July 2015).

50. High Quality Factory Manufacture Biomass Briquette Carbonization Furnace. Available online: http:/ /www. alibaba.com/product-detail/High-quality-factory-manufacture-biomass-briquette_1896817002.html (accessed on 4 April 2015).

51. Fact Foundation. The Jatropha Handbook from Cultivation to Application. 2010. Available online: http: / /www.snvworld.org/files / / fact_foundation_jatropha_handbook_2010.pdf (accessed on 29 March 2015).

52. Energy Commission. Charcoal Price Tracking in Major Urban Centres of Ghana. 2014. Available online: http://energycom.gov.gh/files/Charcoal\%20Price\%20Tracking\%20_January\%20to\%20_December\% 202013.pdf (accessed on 5 April 2015).

53. 20KVA Soundproof Diesel Generator Powered by Perkins. Available online: http://www.alibaba. com/product-detail/20KVA-Soundproof-Diesel-Generator-Powered-by_60265698698.html?spm=a2700. 7724857.35.1.iF073v (accessed on 2 May 2016).

54. CE ISO 10KVA-1250KVA biogas generator price. Available online: http://www.alibaba.com/product-detail/ CE-ISO-10KVA-1250KVA-biogas-generator_60088055040.html?spm=a2700.7724857.35.1.4nDNvS (accessed on 3 August 2015).

55. Public Utility Regulatory Commission. Approved Feed in Tariff Rate in Ghana. 2014. Available online: http://www.purc.com.gh/purc/sites/default/files/fit_2014.pdf (accessed on 21 August 2015).

56. Henning, R. Identification, Selection and Multiplication of High Yielding Jatropha curcas L. Plants and Economic Key Points for Viable Jatropha Oil Production Costs. In Presented at the International Consultation on Pro-Poor Jatropha Development, Rome, Italy, 10-11 April 2008; Available online: https:/ /www.ifad.org/ documents /10180/0574242c-a63b-43d8--986c-fdd906f8128b (accessed on 11 October 2015).

57. Pot Tipper Kettle Tank Complete Soap Maker. Available online: http://www.soapmelters.com/Pot-TipperComplete-Soap-Equipment-With-Heat-Mix-p/pot\%20tipper\%20c.htm (accessed on 13 August 2015).

58. Caustic Soda prices. Available online: http://www.alibaba.com/product-detail/Caustic-Soda_1948037717. html?spm=a2700.7724857.35.1.pedyJi\&s=p (accessed on 10 August 2015).

59. Professional Large Production Soap Molds. Available online: http://soapequipment.com/lpmolds/ \#Manual_Cutter_Soap_Mold_-_Model_MCM2C (accessed on 2 August 2015).

60. Manual Cutter. Available online: http://soapequipment.com/mcutter/ (accessed on 2 September 2015).

61. Pneumatic Bath Bomb Press. Available online: http://soapequipment.com/bathbomb/ (accessed on 16 July 2015).

62. Soap Drying Trays and Racks. Available online: http://soapequipment.com/trays/ (accessed on 20 September 2015).

63. Van de Kamp, R.M.; Willson, B.G.; Mark, E.; Singley, M.E.; Tom, L.; Richard, L.T.; Kolega, J.J.; Gouin, R.F.; Lalibery, L.; Kay, D.; et al. On-Farm Composting Hand Book; NRAES-54; Natural Resource, Agriculture, and Engineering Service, Cooperative Extension: New York, NY, USA, 1992. 
64. Sarpong, S.Y. Co-Composting Organic Solid Waste with Moringa Oleifera Leaves, Sawdust and Grass Clippings. Master's Thesis, Kwame Nkrumah University of Science and Technology, Kumasi, Ghana, 2014.

65. Chen, L.; de Haro, M.M.; Moore, A.; Falen, C. The Composting Process. Available online: http:/ /www.cals. uidaho.edu/edcomm/pdf/CIS/CIS1179.pdf (accessed on 17 August 2015).

66. Compost screen sieve. Available online: http://www.alibaba.com/product-detail/Greatly-welcomedCompost-trommel-screen-sieve_1749472131.html?spm=a2700.7724857.35.14.p712Ev (accessed on 13 June 2015).

67. Stainless Steel Compost Thermometer. Available online: http://www.alibaba.com/product-detail/ Stainless-Steel-Compost-Thermometer_675547220.html?spm=a2700.7724838.35.1.935CLd\&s=p (accessed on 11 September 2015).

(C) 2016 by the authors; licensee MDPI, Basel, Switzerland. This article is an open access article distributed under the terms and conditions of the Creative Commons Attribution (CC-BY) license (http://creativecommons.org/licenses/by/4.0/). 